\title{
Article \\ Sulfidizing Behavior of Complex Lead-Silver Ore: A Flotation Study
}

\author{
Yibing Zhang ${ }^{1}$ and Jianhua Chen ${ }^{1,2,3,4, *}$ \\ 1 School of Chemistry and Chemical Engineering, Guangxi University, Nanning 530004, China; \\ 2014401010@st.gxu.edu.cn \\ 2 School of Resources, Environment and Materials, Guangxi University, Nanning 530004, China \\ 3 Guangxi Colleges and University Key Laboratory of Minerals Engineering, Nanning 530004, China \\ 4 Guangxi Key Laboratory of Processing for Non-ferrous Metal and Featured Materials, Guangxi University, \\ Nanning 530004, China \\ * Correspondence: jhchen@gxu.edu.cn
}

check for

updates

Citation: Zhang, Y.; Chen, J. Sulfidizing Behavior of Complex Lead-Silver Ore: A Flotation Study. Minerals 2021, 11, 434. https:// doi.org/10.3390/min11040434

Academic Editor: William Skinner

Received: 13 March 2021

Accepted: 15 April 2021

Published: 20 April 2021

Publisher's Note: MDPI stays neutral with regard to jurisdictional claims in published maps and institutional affiliations.

Copyright: (c) 2021 by the authors. Licensee MDPI, Basel, Switzerland. This article is an open access article distributed under the terms and conditions of the Creative Commons Attribution (CC BY) license (https:/ / creativecommons.org/licenses/by/ $4.0 /)$.

\begin{abstract}
In this study, we investigate a low-grade oxidized lead ore containing noble metal silver, with complex mineralogy. The sulfurization behaviors of different types of lead-silver minerals at different $\mathrm{pH}$ values were analyzed using the chemical phase analysis method. The interactions between different types of lead-silver minerals and different types of collectors were investigated. An effective laboratory process was developed, and closed-circuit tests were carried out at industrial sites. We found that the order of difficulty for sulfidizing various lead minerals and silver minerals was $\left(\mathrm{PbFe}_{6}(\mathrm{OH})_{12} \mathrm{SO}_{4}\right)_{4}<\mathrm{PbCO}_{3}<\mathrm{PbSO}_{4}<\mathrm{Pb}_{5}\left(\mathrm{P} / \mathrm{As} / \mathrm{VO}_{4}\right)_{3} \mathrm{Cl} ; \mathrm{Ag}_{2} \mathrm{AsS}_{2}<\mathrm{AgCl}<$ natural-Ag. Aerophine 3418A had the best selectivity and capture capacity of the silver minerals. In the laboratory, the total recovery of lead and silver was $65.16 \%$ and $87.81 \%$, respectively. In industrial closed-circuit testing, flotation alone was used, which produced a total lead recovery yield of $67.71 \%$, and a total silver recovery yield of $87.64 \%$.
\end{abstract}

Keywords: oxide lead ore; silver mineral; low grade; flotation

\section{Introduction}

The Three Rivers (Sanjiang) region, which is one of the sixteen most famous regions in China, is an important source of Chinese nonferrous metals, where hundreds of deposits such as copper, lead, zinc, and silver are found. The so-called Three Rivers refers to China's Jinsha River, Nu River, and the Lancang River. Mixed sulfide-oxide ores with extremely complex mineralogy are often found near this area. A low-grade complex oxidized lead ore taken from this area is tested in this study. This type of ore is very difficult to deal with from a mineral-processing point of view due to its complex mineralogy. Nevertheless, because of its large reserves, this type of low-grade complex oxidized lead ore is still of great significance [1,2].

It is generally known that sulfide minerals can be effectively recovered by conventional collectors such as xanthate or dithiophosphate. However, the separation between minerals is difficult. In contrast, oxidized minerals are difficult to float directly because of their higher solubilities, as well as the extensive hydration of their surfaces. Under normal conditions, the surfaces of oxidized minerals can be sulfurized by the addition of sulfide salts such as sodium sulfide, thereby reducing their solubility and hydration to facilitate the adsorption of conventional reagents on the surface [3-9]. The reactions are given as follows:

$$
\begin{gathered}
\mathrm{Na}_{2} \mathrm{~S}_{(\mathrm{S})} \rightarrow 2 \mathrm{Na}^{+}{ }_{(\mathrm{aq})}+\mathrm{S}^{2-}{ }_{(\mathrm{aq})} \\
\mathrm{PbCO}_{3(\mathrm{~s})}+\mathrm{S}^{2-}{ }_{(\mathrm{aq})} \rightarrow \mathrm{PbS}_{(\mathrm{s})}+\mathrm{CO}_{3}{ }^{2-}{ }_{(\mathrm{aq})}
\end{gathered}
$$


It has been found that the surfaces of oxidized lead minerals could be converted to a more insoluble lead sulfide by adding sulfide salts. Therefore, oxidized lead minerals could be collected by xanthate, and the consumption of the collectors could be reduced [10]. It is evident that $\mathrm{pH}$, reaction time, and the method of conditioning have a significant impact on the solubility behavior of lead oxide minerals [11-15]. Lead ions in the solution can be reabsorbed as hydroxy complexes on the surface, activating or depressing the mineral As, depending on the $\mathrm{pH}$ of the solution [16]. A sulfidization flotation method has been used to investigate the recovery of lead and silver. Moreover, xanthate and dithiophosphate were used as collectors in the studies [17-19]. The flotation results indicated that Aerophine 3418A had excellent selectivity, which could dramatically reduce the total consumption of the collectors [19]. The effect of the addition of sodium sulfide on the pulp potential and amyl xanthate flotation of cerussite and galena was reported. It was found that the optimal flotation conditions occurred when the dose of sodium sulfide set the pulp potential in the range from $-100 \mathrm{mv}$ to $150 \mathrm{mv}[20,21]$.

Due to the complex mineralogy of the minerals, different separation methods were used at different stages $[13,15]$. Research on minerals with extremely complex mineralogy is relatively rare, and therefore this study is an attempt to fill this gap.

The paper is organized as follows: In Section 3.1, we describe the sulfurization flotation behavior of lead oxide minerals in lead-silver ore and that of various silver minerals. Sodium sulfide $\left(\mathrm{Na}_{2} \mathrm{~S}\right)$ is a typical depressant of sulfide minerals and its depression behavior has been clearly investigated [11,12], therefore, the sulfide minerals that can be easily depressed by $\mathrm{Na}_{2} \mathrm{~S}$ are not analyzed in this part; in Section 3.2, we test the effect of several collectors on the flotation recovery of silver minerals; in Section 3.3, we design a complete flotation process, and then an industrial closed-circuit test is carried out.

\section{Materials}

\subsection{Samples}

The complex $\mathrm{Pb}-\mathrm{Ag}$ ore sample investigated in this study was provided by the Huachangshan Mining Company, which is located in the Three Rivers (Sanjiang) region in LanPing county, Yunnan province, China. The ore of the Huachangshan deposit has laminar structure, banded structure, primary breccia structure, allomorphic granular structure, sulfide mold structure, and characteristics of the development of barite and siliceous rocks with hydrothermal characteristics. The characteristics of trace elements, rare earth elements, mineralogy and petrology of siliceous rocks in the Sanhedong formation of the Upper Triassic show the characteristics of submarine sedimentary hydrothermal (SEDEX) deposits. The wall rock alteration related to lead-silver mineralization is mainly silicification, carbonation, dolomitization, and fluoritization [22-24].

An X-ray fluorescence (XRF) spectrometry and chemical phase analysis were used to determine the compositions of the samples, and the results are shown in Tables 1 and 2, respectively.

Table 1. X-ray fluorescence (XRF) spectrometry results of complex oxidized Pb-Ag ore sample (mass fraction, $\%$ ).

\begin{tabular}{cccc}
\hline Species & Content & Species & Content \\
\hline $\mathrm{CaO}$ & 36.1 & $\mathrm{Fe}$ & 1.77 \\
$\mathrm{MgO}$ & 5.03 & $\mathrm{Mn}$ & 0.12 \\
$\mathrm{SiO}_{2}$ & 4.1 & $\mathrm{~V}$ & 0.18 \\
$\mathrm{Al}_{2} \mathrm{O}_{3}$ & 0.6 & $\mathrm{Cd}^{\mathrm{a}}$ & 112 \\
$\mathrm{~K}_{2} \mathrm{O}$ & 0.14 & $\mathrm{Mo}^{\mathrm{a}}$ & 24 \\
$\mathrm{~Pb}$ & $\mathrm{Sb}^{\mathrm{a}}$ & 800 \\
$\mathrm{Zn}$ & $\mathrm{As}$ & 0.66 \\
$\mathrm{Ag}$ & $\mathrm{S}$ & $\mathrm{S}$ & 0.28 \\
$\mathrm{Cu}$ & 0.43 & & \\
\hline a Units in $\mathrm{g} / \mathrm{t}(\mathrm{g} / \mathrm{t}$ is short for gram per ton).
\end{tabular}

${ }^{a}$ Units in $\mathrm{g} / \mathrm{t}(\mathrm{g} / \mathrm{t}$ is short for gram per ton). 
Table 2. Chemical phase analysis results of complex sulfide-oxidized mixed $\mathrm{Pb}-\mathrm{Ag}$ ore sample (mass fraction, $\mathrm{g} / \mathrm{t}$, \%).

\begin{tabular}{cccccccc}
\hline Species & Natural-Ag & $\mathbf{A g}_{2} \mathbf{A s S}_{\mathbf{2}}$ & $\mathbf{A g C l}$ & $\mathbf{C u F e S}_{\mathbf{2}}$ & $\mathbf{P b S}$ & $\mathbf{S i O}_{\mathbf{2}}$ and Silicate & Total Ag \\
\hline $\mathrm{Ag}(\mathrm{g} / \mathrm{t})$ & 21 & 42.5 & 63 & 1.3 & 15 & 34.2 & 177 \\
\hline $\mathrm{Species}$ & $\mathrm{Pb}_{5}\left(\mathrm{P} / \mathrm{As} / \mathrm{VO}_{4}\right)_{3} \mathrm{Cl} \mathrm{PbCO}$ & $\mathrm{PbS}$ & $\mathrm{PbSO}_{4}$ & $\left(\mathrm{PbFe}_{6}(\mathrm{OH})_{12} \mathrm{SO}_{4}\right)_{4}$ & 0.46 & $\mathrm{Total} \mathrm{Pb}$ \\
$\mathrm{Pb}(\%)$ & 1.24 & 1.01 & 0.16 & 0.09 & 2.96 & 26 \\
\hline
\end{tabular}

$\left(\mathrm{Pb}_{5}\left(\mathrm{P} / \mathrm{As} / \mathrm{VO}_{4}\right)_{3} \mathrm{Cl}\right.$ is shorthand for $\mathrm{Pb}_{5}\left(\mathrm{PO}_{4}\right)_{3} \mathrm{Cl}, \mathrm{Pb}_{5}\left(\mathrm{AsO}_{4}\right)_{3} \mathrm{Cl}$ and $\left.\mathrm{Pb}_{5}\left(\mathrm{VO}_{4}\right)_{3} \mathrm{Cl}\right)$.

X-ray fluorescence (XRF) spectrometry used the original X-ray photons or other microscopic particles to excite the atoms in the substances to be detected, and therefore produced secondary characteristic $\mathrm{X}$-rays ( $\mathrm{X}$ photofluorescence) for chemical composition analysis and chemical research [25].

Chemical phase analysis was based on the differences of solubility and dissolution rate of various minerals (or compounds) in chemical solvents. Chemical methods were used to determine the percentages of different compounds composed of the same elements in the sample. Different solvents were selected for selective separation of each phase, and then the composition or structure of each phase was determined by chemical or physical methods. We used this analysis method to determine mineral species and found that the chemical phase analysis method was more accurate than XRD spectrometry for determining mineral species [26].

According to the results of XRF spectrometry in Table 1, in general, the sample contained $2.96 \% \mathrm{~Pb}$, and $177 \mathrm{~g} / \mathrm{t} \mathrm{Ag}$, from which it could be seen that the main precious metals in this sample were all at a relatively low level. Table 2 shows that the Ag mineral was found mainly in $\mathrm{AgCl}(63 \mathrm{~g} / \mathrm{t}), \mathrm{Ag}_{2} \mathrm{AsS}_{2}(42.5 \mathrm{~g} / \mathrm{t}), \mathrm{SiO}_{2}$, and silicate $(34.2 \mathrm{~g} / \mathrm{t})$, natural$\mathrm{Ag}(21 \mathrm{~g} / \mathrm{t}), \mathrm{PbS}(15 \mathrm{~g} / \mathrm{t})$, and $\mathrm{CuFeS}_{2}(1.3 \mathrm{~g} / \mathrm{t})$. These different $\mathrm{Ag}$ minerals accounted for $35.6 \%, 24 \%, 19.3 \%, 11.9 \%, 8.5 \%$, and $0.7 \%$ of the total $\mathrm{Ag}$, respectively. $\mathrm{Pb}$ was found mainly in $\mathrm{Pb}_{5}\left(\mathrm{P} / \mathrm{As} / \mathrm{VO}_{4}\right)_{3} \mathrm{Cl}\left(1.24 \%\right.$ in content), $\mathrm{PbCO}_{3}(1.01 \%$ in content $),\left(\mathrm{PbFe}_{6}(\mathrm{OH})_{12} \mathrm{SO}_{4}\right)_{4}$ $\left(0.46 \%\right.$ in content), $\mathrm{PbS}(0.16 \%$ in content $)$ and $\mathrm{PbSO}_{4}(0.09 \%$ in content). They accounted for $41.9 \%, 34.2 \%, 15.5 \%, 5.4 \%$, and $3 \%$ of the total $\mathrm{Pb}$, respectively.

The sample was also analyzed using X-ray diffraction (XRD), and the results revealed that there were 42 types of minerals in this sample. Principal among them were teallite$(\mathrm{Pb}, \mathrm{Sn}) \mathrm{S}$, cerussite-syn- $\mathrm{PbCO}_{3}$, vanadinite- $\mathrm{Pb}_{5}\left(\mathrm{VO}_{4}\right)_{3} \mathrm{Cl}$, mimetite-syn- $\mathrm{Pb}_{5}\left(\mathrm{AsO}_{4}\right)_{3} \mathrm{Cl}$, clinomimetite- $\mathrm{Pb}_{5}\left(\mathrm{AsO}_{4}\right)_{3} \mathrm{Cl}$, crocoite-syn- $\mathrm{PbCrO}_{4}$, uchucchacuaite- $\mathrm{AgMnPb}_{3} \mathrm{Sb}_{5} \mathrm{~S}_{12}$, dervillite- $\mathrm{Ag}_{2} \mathrm{AsS}_{2}$, chalcopyrite-CuFeS 2 , calcite- $\mathrm{CaCO}_{3}$, dolomite- $\mathrm{CaMg}\left(\mathrm{CO}_{3}\right)_{2}$, tachyhydritesyn- $\mathrm{CaMg}_{2} \mathrm{C}_{16} \cdot 12 \mathrm{H}_{2} \mathrm{O}$, and hemimorphite- $\mathrm{Zn}_{4} \mathrm{Si}_{2} \mathrm{O}_{7}(\mathrm{OH})_{2} \cdot \mathrm{H}_{2} \mathrm{O}$.

The above results suggest that the composition of this ore sample is very complex. It is a sulfide-oxidized mixed ore with high oxidation rate.

\subsection{Experiments}

The sample was wet ground to $88 \%(w / w)$ below $0.074 \mathrm{~mm}$ in a ball mill. A $300 \mathrm{~g}$ ground sample was added to an XFG single-trough flotation machine at a volume of $1.0 \mathrm{dm}^{3}$, with the impeller speed set at $2000 \mathrm{rpm}$. All the experiments were conducted under standard atmospheric pressure and an average temperature of $32{ }^{\circ} \mathrm{C}$ (the average temperature of the laboratory environment during the test period).

In all flotation tests, $\mathrm{Na}_{2} \mathrm{SiO}_{3} \cdot 9 \mathrm{H}_{2} \mathrm{O}$ (glass water) and $\mathrm{Na}_{2} \mathrm{CO}_{3}$ were used as depressants. Sodium sulfide $\left(\mathrm{Na}_{2} \mathrm{~S}\right)$ was used as an activator for the oxidized $\mathrm{Pb}$ minerals. N-butyl xanthate (NBX) and Aerophine 3418A were used as collectors, and Methyl Isobutyl Carbinol (MIBC) was chosen as frother. All the reagents used or tested (except 3418A) in this study were provided by the Zhuzhou Flotation Reagents Factory in Hunan Province, and 3418A was provided by the Solvay Company, Shanghai, China. All these reagents were analytical grade.

Each group of experiments was repeated twice to ensure the accuracy of the experimental results. 


\section{Results and Discussion}

Ores that have undergone partial or strong oxidation during formation of the orebody usually have the character of containing both sulfide ores and oxidized ores [27]. Dealing with these types of oxidized ores requires a combination of collectors, excessive amounts of reagents, the use of sodium sulfide $\left(\mathrm{Na}_{2} \mathrm{~S}\right)$, and also a staged preferential flotation. In industry, the most stable oxidized lead flotation procedure is to sulfurize the ore in advance, and then collect by xanthate, which is called the sulfurization-xanthate method in China [28]. As for the silver mineral, pulp pH and collector types are critical to its recovery. Although some silver ores exist in an elemental state or a combined state, most of them can be found in either lead or both lead and zinc concentrates, or even distributed in gangue.

In this study, the grades of different types of lead and silver minerals are tested by chemical phase analysis, and therefore the recovery rates of different types of minerals can subsequently be calculated.

\subsection{Sulfidizing Flotation Behavior}

To test the sulfurization behaviors of different types of lead oxide minerals and various silver minerals at different $\mathrm{pH}$ values, in these experiments, the dosage of $\mathrm{Na}_{2} \mathrm{~S}$ was gradually increased from 1 to $10 \mathrm{~kg} / \mathrm{t}$, and the recovery rates of lead and silver minerals were used to measure the effectiveness of the sulfidizing flotation behavior. Each group of experiments used $300 \mathrm{~g}$ of wet-ground sample in a $1.0 \mathrm{dm}^{3}$ flotation cell, and the same amount of reagent was used in each group. Regular reagents used were $500 \mathrm{~g} / \mathrm{t}$ $\mathrm{Na}_{2} \mathrm{SiO}_{3} \cdot 9 \mathrm{H}_{2} \mathrm{O}$ and $500 \mathrm{~g} / \mathrm{t} \mathrm{Na} \mathrm{CO}_{3}, \mathrm{Na}_{2} \mathrm{~S}$ was used as an activator, and $500 \mathrm{~g} / \mathrm{t} \mathrm{NBX}$ was used as the collector. The flowchart for the $\mathrm{Na}_{2} \mathrm{~S}$ dosage test is shown in Figure 1. Pulp pH at different dosages of $\mathrm{Na}_{2} \mathrm{~S}$ is displayed in Table A1, Appendix A.

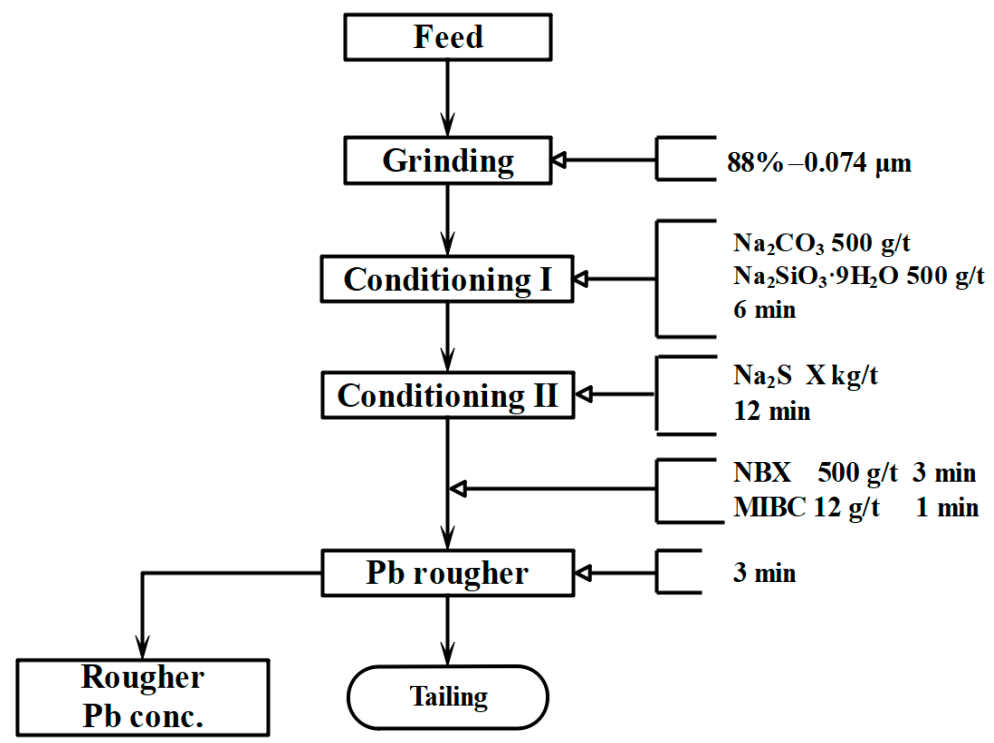

Figure 1. The flowchart of the $\mathrm{Na}_{2} \mathrm{~S}$ dosage test.

The flotation recovery of lead oxide minerals at different dosages of $\mathrm{Na}_{2} \mathrm{~S}$ are shown in Figure 2a. From Figure 2a, the following can be concluded: (I) The overall trend of the recovery of $\left(\mathrm{PbFe}_{6}(\mathrm{OH})_{12} \mathrm{SO}_{4}\right)_{4}$ is upward, which suggests that a high dosage of $\mathrm{Na}_{2} \mathrm{~S}$ is beneficial for recovering $\left(\mathrm{PbFe}_{6}(\mathrm{OH})_{12} \mathrm{SO}_{4}\right)_{4}$; (II) The recovery of $\mathrm{PbSO}_{4}, \mathrm{PbCO}_{3}$, and $\mathrm{Pb}_{5}\left(\mathrm{P} / \mathrm{As} / \mathrm{VO}_{4}\right)_{3} \mathrm{Cl}$ are relatively stable. The $\mathrm{PbCO}_{3}$ is on the rise, reaching its peak at $10 \mathrm{~kg} / \mathrm{t}$ at a recovery rate of $59.86 \%$, while the $\mathrm{PbSO}_{4}$ shows slow growth from $32.21 \%$ at $1 \mathrm{~kg} / \mathrm{t}$ to $41.07 \%$ at $10 \mathrm{~kg} / \mathrm{t}$, which suggests that the recovery rates of $\mathrm{PbSO}_{4}$ and $\mathrm{PbCO}_{3}$ increase with an increasing $\mathrm{Na}_{2} \mathrm{~S}$ dosage, and $\mathrm{PbCO}_{3}$ is affected more than $\mathrm{PbSO}_{4}$; (III) The recovery rate of $\mathrm{Pb}_{5}\left(\mathrm{P} / \mathrm{As} / \mathrm{VO}_{4}\right)_{3} \mathrm{Cl}$ is the lowest, leveling off below $20 \%$. As for the barely changed curve, the $\mathrm{Pb}_{5}\left(\mathrm{P} / \mathrm{As} / \mathrm{VO}_{4}\right)_{3} \mathrm{Cl}$ recovery has nothing to do with the variance in 
the $\mathrm{Na}_{2} \mathrm{~S}$ dosage. In summary, the order of difficulty for sulfidizing all types of lead oxide minerals was $\left(\mathrm{PbFe}_{6}(\mathrm{OH})_{12} \mathrm{SO}_{4}\right)_{4}<\mathrm{PbCO}_{3}<\mathrm{PbSO}_{4}<\mathrm{Pb}_{5}\left(\mathrm{P} / \mathrm{As} / \mathrm{VO}_{4}\right)_{3} \mathrm{Cl}$.
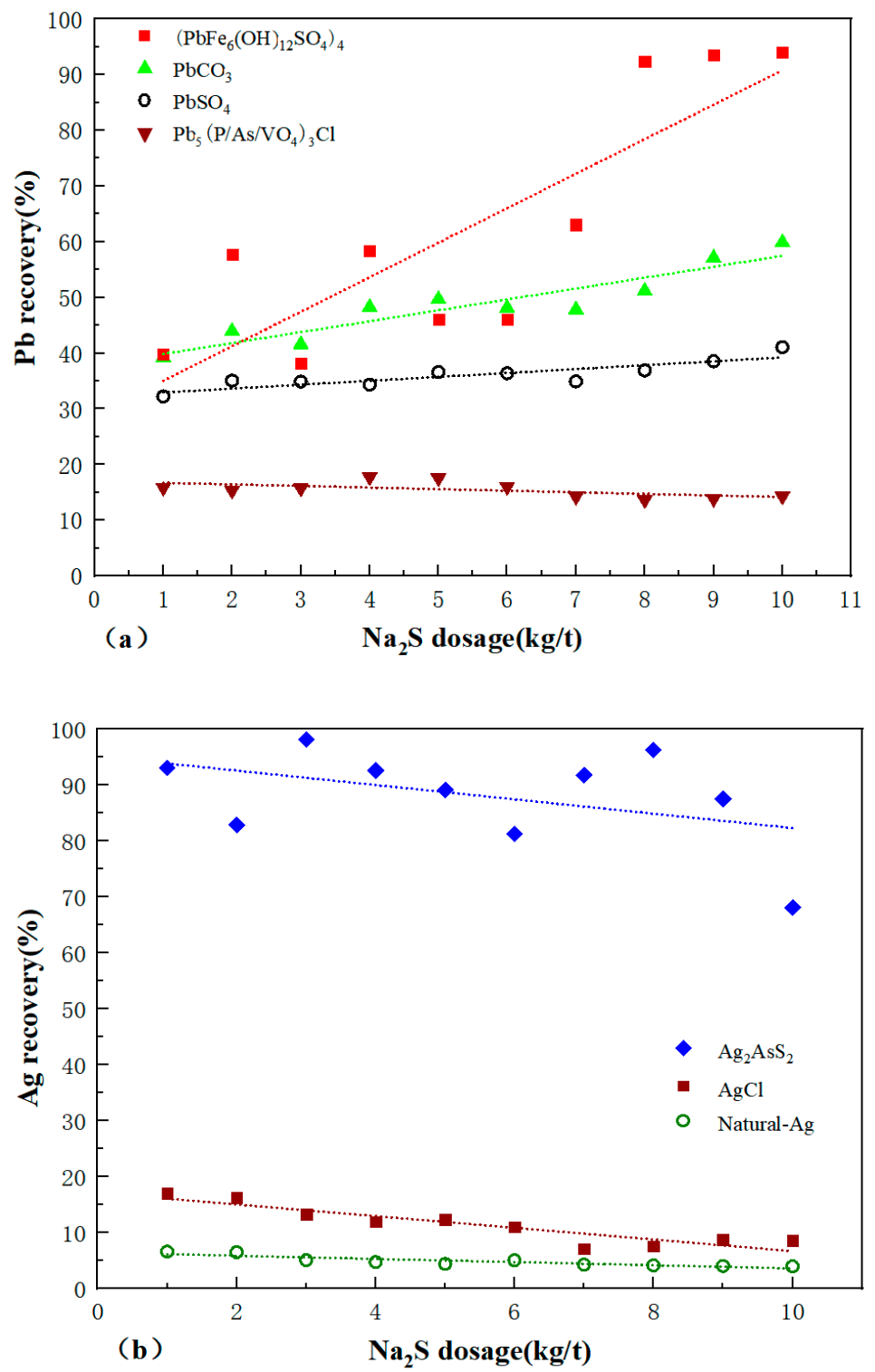

Figure 2. Flotation recovery at different dosages of $\mathrm{Na}_{2} \mathrm{~S}$. (a) $\mathrm{Pb}$ recovery of $\left(\mathrm{PbFe}_{6}(\mathrm{OH})_{12} \mathrm{SO}_{4}\right)_{4}$, $\mathrm{PbCO}_{3}, \mathrm{PbSO}_{4}$, and $\mathrm{Pb}_{5}\left(\mathrm{P} / \mathrm{As} / \mathrm{VO}_{4}\right)_{3} \mathrm{Cl}$; (b) Ag recovery of $\mathrm{Ag}_{2} \mathrm{AsS}_{2}, \mathrm{AgCl}$, and natural-Ag.

The flotation recovery of $\mathrm{Ag}$ minerals at different dosages of $\mathrm{Na}_{2} \mathrm{~S}$ is shown in Figure 2b. The following is illustrated in Figure 2b: (I) The mineral $\mathrm{Ag}_{2} \mathrm{AsS}_{2}$ is relatively easy to recover with a recovery rate that is around $90 \%$ below $5 \mathrm{~kg} / \mathrm{t}$ of $\mathrm{Na}_{2} \mathrm{~S}$. The overall trend of this curve is a decline, that is to say, a high level of $\mathrm{Na}_{2} \mathrm{~S}$ usage acts as one type of depressant in $\mathrm{Ag}_{2} \mathrm{AsS}_{2}$ flotation. (II) Considering $\mathrm{AgCl}$, the recovery rate gradually decreases with an increase in $\mathrm{Na}_{2} \mathrm{~S}$ from a peak of $17 \%$ at $1 \mathrm{~kg} / \mathrm{t}$, down to $8.55 \%$ at $10 \mathrm{~kg} / \mathrm{t}$. During this process, it clearly becomes further depressed. (III) In terms of natural- $\mathrm{Ag}$, in spite of an increase in $\mathrm{Na}_{2} \mathrm{~S}$ usage, the recovery rate is constant at about $6 \%$, which suggests that the dosage of $\mathrm{Na}_{2} \mathrm{~S}$ used for the recovery of natural-Ag does not have any impact. Thus, the the order of difficulty for sulfidizing these types of silver minerals was $\mathrm{Ag}_{2} \mathrm{AsS}_{2}$ $<\mathrm{AgCl}<$ natural-Ag.

Figure 2 illustrates the recovery rate of different types of $\mathrm{Pb}$ minerals and $\mathrm{Ag}$ minerals, which change according to the dosage of $\mathrm{Na}_{2} \mathrm{~S}$. Figure 3 shows the recovery of total $\mathrm{Ag}$ and 
$\mathrm{Pb}$ at different dosages of $\mathrm{Na}_{2} \mathrm{~S}$. The recovery rate of total $\mathrm{Pb}$ presents an upward trend overall, from the lowest value of $11.49 \%$ to the highest value of $30.79 \%$. On the contrary, it is found that the recovery rate of total Ag overall exhibits a downward trend, from the highest value of $33.73 \%$ to a minimum of $22.85 \%$.

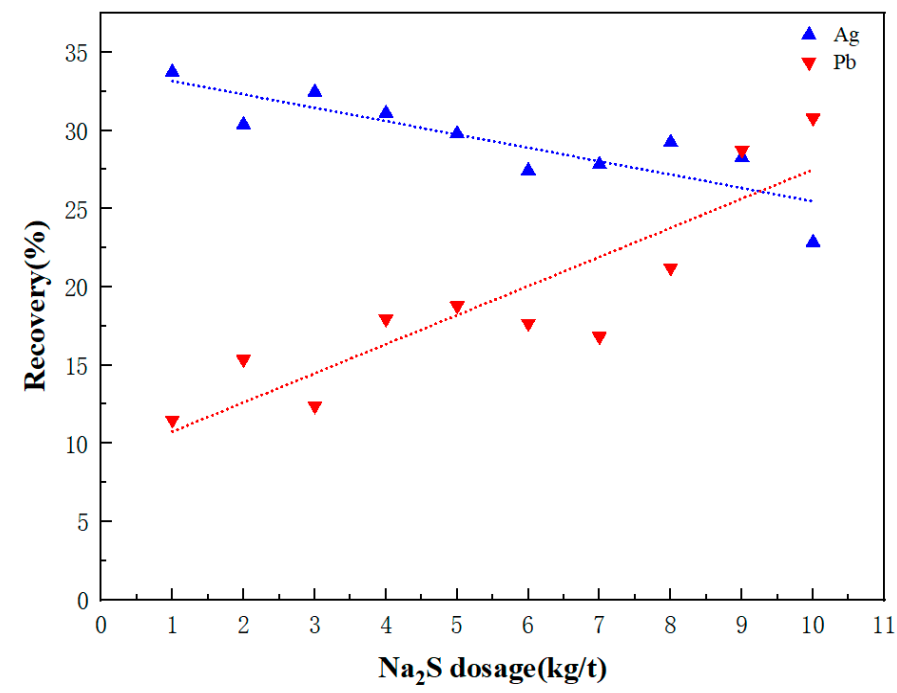

Figure 3. Flotation recovery of total $\mathrm{Ag}$ and $\mathrm{Pb}$ at different dosages of $\mathrm{Na}_{2} \mathrm{~S}$.

The trends of the two curves show that an increase in the dosage of $\mathrm{Na}_{2} \mathrm{~S}$ is beneficial to the recovery of $\mathrm{Pb}$, and detrimental to the recovery of $\mathrm{Ag}$. Whatever reagent dosage is used, these two metals cannot be optimally recovered at the same time. Therefore, the flotation process should be performed in two stages, one each for the recycling of $\mathrm{Pb}$ and $\mathrm{Ag}$. The first stage should focus on the recovery of $\mathrm{Ag}$, while the second stage focuses on the recovery of $\mathrm{Pb}$ with the sulfurization-xanthate method. In addition, because the two curves intersect at around $9 \mathrm{~kg} / \mathrm{t}$, the optimum $\mathrm{Na}_{2} \mathrm{~S}$ dosage for the second stage is $9 \mathrm{~kg} / \mathrm{t}$.

\subsection{Selection of $A g$ Flotation Collectors}

In Section 3.1, it was concluded that the first stage of the flotation process should give priority to silver recovery, thus, nullifying the effect of $\mathrm{Na}_{2} \mathrm{~S}$ on silver recovery in the second stage. After a series of flotation reagents tests, $70 \mathrm{~g} / \mathrm{t}$ dithiophosphate BA(DBA), $300 \mathrm{~g} / \mathrm{t}$ dithiophosphate BA(DBA), $20 \mathrm{~g} / \mathrm{t} 3418 \mathrm{~A}, 100 \mathrm{~g} / \mathrm{t}$ alkyl hydroximic acid (AHDA), and $100 \mathrm{~g} / \mathrm{t}$ dodecyl mercaptan (DDM) were selected to estimate their collecting capacity and selectivity. The flowchart is shown in Figure 4 and the comparison results are shown in Figure 5. Under the conditions of using these five reagents separately, from Figure 5a,b the following can be observed:

I Ag recovery increased in the order $100 \mathrm{~g} / \mathrm{t} \mathrm{DDM}<100 \mathrm{~g} / \mathrm{t}$ AHDA $<70 \mathrm{~g} / \mathrm{t}$ DBA $<$ $300 \mathrm{~g} / \mathrm{t}$ DBA $<20 \mathrm{~g} / \mathrm{t} 3418 \mathrm{~A}$;

II $\mathrm{Pb}$ recovery increased in the order $100 \mathrm{~g} / \mathrm{t}$ DDM $<20 \mathrm{~g} / \mathrm{t} \mathrm{3418A}<70 \mathrm{~g} / \mathrm{t} \mathrm{DBA}<$ $300 \mathrm{~g} / \mathrm{t}$ DBA $<100 \mathrm{~g} / \mathrm{t}$ AHDA;

III The yield of the product increased in the order $100 \mathrm{~g} / \mathrm{t}$ DDM $\approx 20 \mathrm{~g} / \mathrm{t} 3418 \mathrm{~A}<70 \mathrm{~g} / \mathrm{t}$ DBA $<300 \mathrm{~g} / \mathrm{t}$ DBA $<100 \mathrm{~g} / \mathrm{t}$ AHDA;

IV The $\mathrm{Pb}$ grade showed small difference in these five products, but the Ag grade is the highest when $20 \mathrm{~g} / \mathrm{t} 3418 \mathrm{~A}$ was used. 


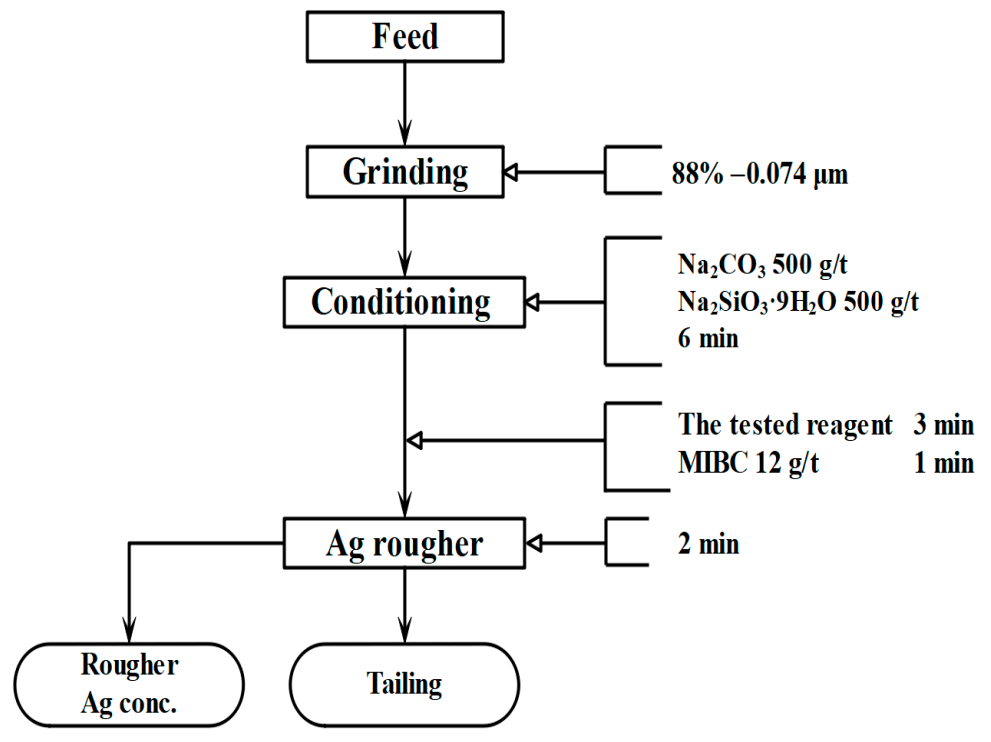

Figure 4. Flowchart of the Ag collector test.

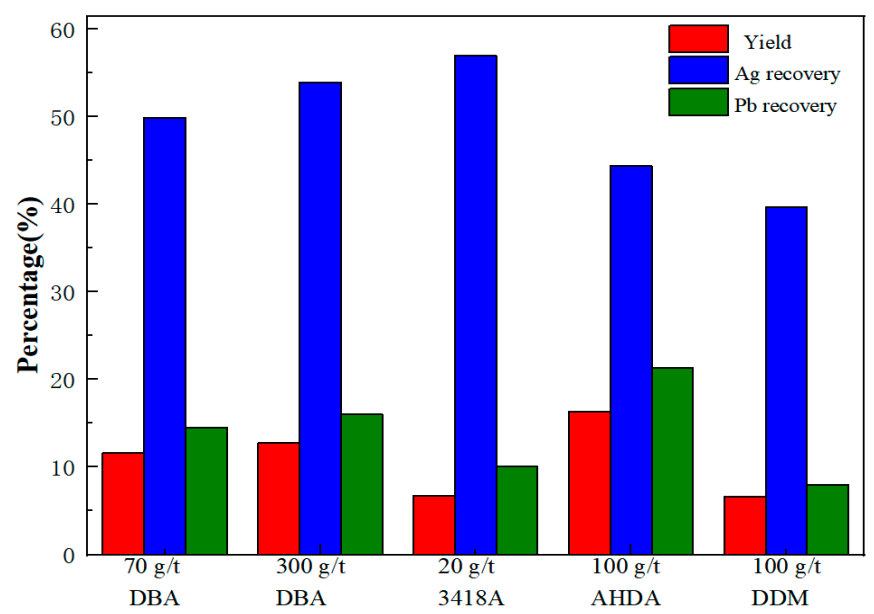

(a) Types of collectors

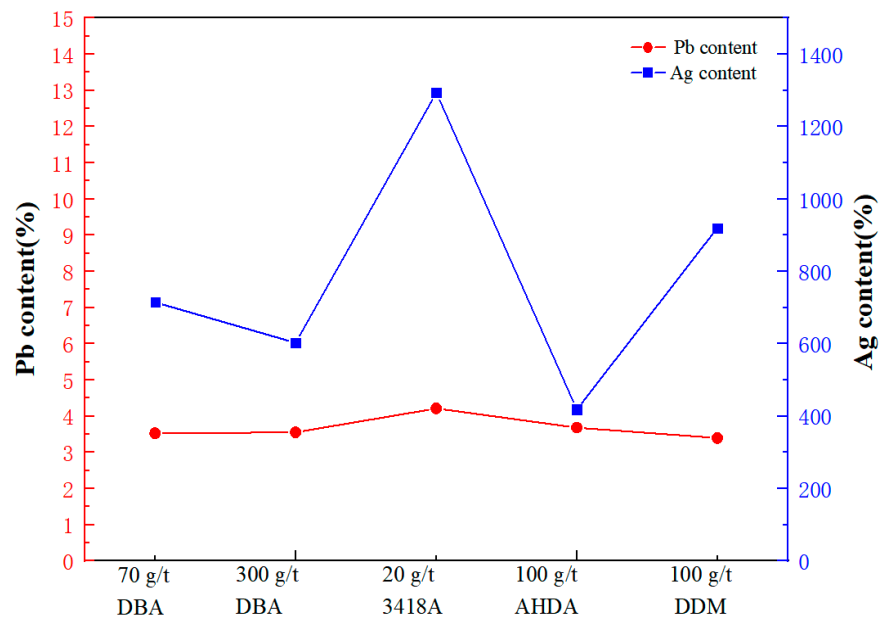

(b)

Types of collectors

Figure 5. (a) Yield and recovery of products under different collector conditions; (b) content of products under different collector conditions. 
When $20 \mathrm{~g} / \mathrm{t} 3418 \mathrm{~A}$ is used, firstly, the product yield is only half of that using $70 \mathrm{~g} / \mathrm{t}$ $\mathrm{DBA}$, but the recovery rate of Ag is the highest among the five collectors, and the recovery rate $\mathrm{Pb}$ is relatively low; secondly, for these five products, the contents of $\mathrm{Pb}$ are similar, while the product of 3418A has an obvious higher grade of Ag than the others. These two points together suggest that 3418A has the best selectivity for Ag, and less selectivity for $\mathrm{Pb}$. The purpose of the first stage of flotation is to strengthen the Ag recovery, as well as weaken the recovery of $\mathrm{Pb}$, which enables the first stage to produce a higher grade of silver concentrate and ensures that the second stage gets a higher grade of lead concentrate at the same time. From the above observations, 3418A is determined to be the primary collector for Ag flotation in the first stage.

\subsection{Laboratory Test and Industrial Closed-Circuit Test}

\subsubsection{Laboratory Test Results}

The laboratory flotation flowchart is shown in Figure 6. After three stages of flotation, four types of products are obtained (rougher $\mathrm{Ag}$ concentrate, rougher $\mathrm{Pb}$ concentrate, scavenger $\mathrm{Pb}$ concentrate, and tailing). NBX at $50 \mathrm{~g} / \mathrm{t}$ is added to strengthen the recovery of $\mathrm{Ag}$ in the Ag flotation stage.

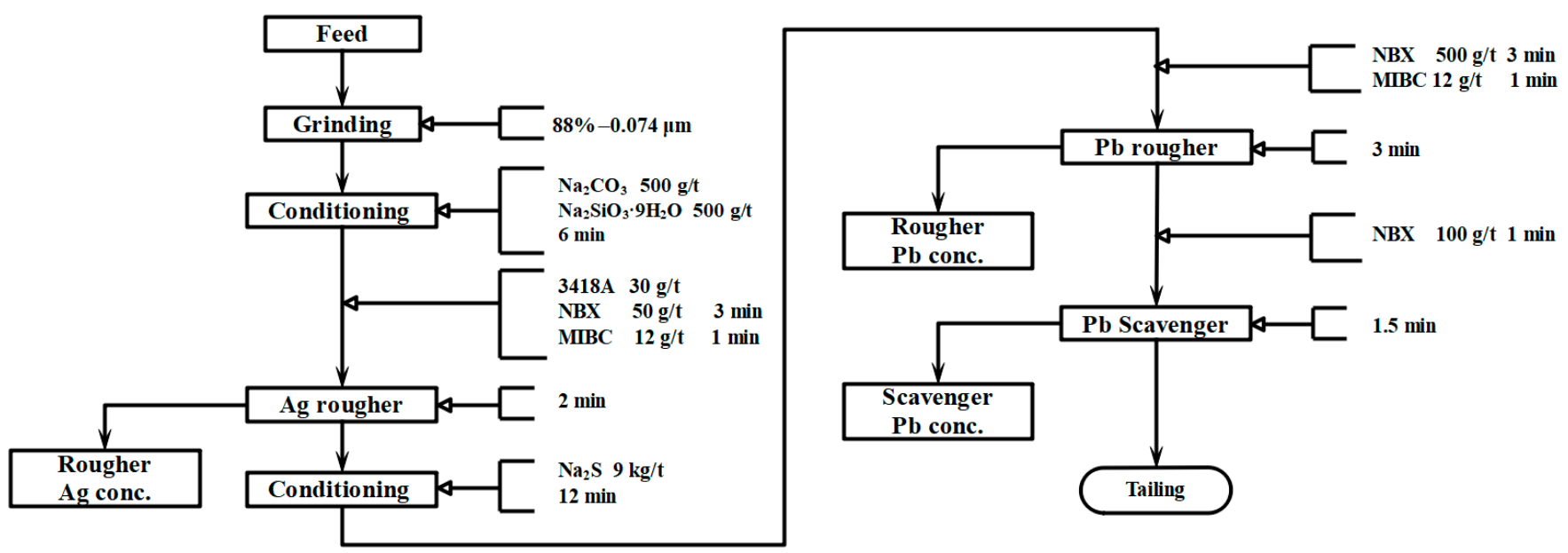

Figure 6. Laboratory flotation flowchart.

The yield, content, and recovery rate of total $\mathrm{Pb}$ and $\mathrm{Ag}$ in the obtained products are shown in Table 3. It was found that rougher Ag concentrate contains $1289.28 \mathrm{~g} / \mathrm{t}$ Ag with $54.98 \%$ recovery, and $4.35 \% \mathrm{~Pb}$ with $11.25 \%$ recovery. Rougher $\mathrm{Pb}$ concentrate contains $475.47 \mathrm{~g} / \mathrm{t} \mathrm{Ag}$ with $23.5 \%$ recovery. For the entire process, the recovery rate of total Ag and total $\mathrm{Pb}$ are $87.81 \%$ and $65.16 \%$, respectively. The grade of $\mathrm{Ag}$ and $\mathrm{Pb}$ are displayed in Tables A2 and A3, which can be found in Appendix A.

Table 3. The yield, grade, and recovery of total $\mathrm{Pb}$ and $\mathrm{Ag}$.

\begin{tabular}{ccccccc}
\hline & & Rougher Ag Conc. & Rougher Pb Conc. & Scavenger Pb Conc. & Tailing & Total \\
\hline \multirow{4}{*}{$\mathrm{Ag}$} & 7.57 & 8.76 & 7.8 & 75.87 & 100 \\
& Yield $(\%)$ & 1289.28 & 475.47 & 208.38 & 27.1 & 177 \\
& Content of total Ag a $(\mathrm{g} / \mathrm{t})$ & 54.98 & 23.5 & 9.33 & 12.19 & 100 \\
\hline \multirow{2}{*}{$\mathrm{Pb} \quad$} & Recovery of total $\mathrm{Ag}(\%)$ & 7.57 & 8.76 & 7.8 & 75.87 & 100 \\
& Yield $(\%)$ & 4.35 & 13.64 & 4.87 & 1.33 & 2.96 \\
& Content of total $\mathrm{Pb}(\%)$ & 11.25 & 40.7 & 13.21 & 34.84 \\
\hline
\end{tabular}

${ }^{\mathrm{a}}$ Units in $\mathrm{g} / \mathrm{t}$. 
In practical terms, Tables 3 and 4 show the following: (I) $\mathrm{Ag}$ within natural- $\mathrm{Ag}, \mathrm{AgCl}$, and $\mathrm{PbS}$ is recovered mainly from the rougher $\mathrm{Ag}$ selection. The recovery rates are $91.52 \%$, $94.42 \%$, and $91.62 \%$, respectively. These three types of Ag are relatively easy to recover; (II) $\mathrm{Ag}$ within $\mathrm{Ag}_{2} \mathrm{AsS}_{2}$ is mainly recovered from the rougher $\mathrm{Pb}$ selection with a recovery rate of $56.31 \%$. Moreover, in the products, rougher $\mathrm{Ag}$ and scavenger $\mathrm{Pb}$, the recovery rates of $\mathrm{Ag}$ within $\mathrm{Ag}_{2} \mathrm{AsS}_{2}$ are $16.71 \%$ and $18.49 \%$. Its total recovery rate is $91.51 \%$; (III) $\mathrm{Ag}$ within $\mathrm{SiO}_{2}$ and Silicate is distributed across the products.

Table 4. The recovery rate of $\mathrm{Ag}(\%)$.

\begin{tabular}{cccccc}
\hline & Rougher Ag Conc. & Rougher Pb Conc. & Scavenger Pb Conc. & Tailing & Total \\
\hline Natural-Ag & 84.36 & 5.15 & 2.01 & 8.48 & 100 \\
$\mathrm{Ag}_{2} \mathrm{AsS}$ & 16.71 & 56.31 & 18.49 & 8.49 & 100 \\
$\mathrm{AgCl}$ & 82.14 & 8.77 & 3.51 & 5.58 & 100 \\
$\mathrm{PbS}$ & 88.78 & 1.92 & 0.92 & 8.38 & 100 \\
$\mathrm{SiO}_{2}$ \& Silicate & 21.35 & 31.46 & 16.71 & 30.48 & 100 \\
\hline
\end{tabular}

Conc. is short for Concentration.

Correspondingly, in Table 5, most of the $\mathrm{PbS}$ is collected from the rougher $\mathrm{Ag}$ selection with a recovery of $90.39 \%$. On the contrary, $\mathrm{PbSO}_{4}, \mathrm{PbCO}_{3}$, and $\left(\mathrm{PbFe}_{6}(\mathrm{OH})_{12} \mathrm{SO}_{4}\right)_{4}$ are collected from the rougher $\mathrm{Pb}$ selection, with recovery rates of $40.81 \%, 61.87 \%$, and $85.03 \%$, respectively, and their total recovery rates are $68.95 \%, 81.09 \%$, and $94.85 \%$, respectively. Unlike the above minerals, $\mathrm{Pb}_{5}\left(\mathrm{P} / \mathrm{As} / \mathrm{VO}_{4}\right)_{3} \mathrm{Cl}$ is too hard to be sulfurized, or to be recovered by $3418 \mathrm{~A}$ or NBX.

Table 5. The recovery rate of $\mathrm{Pb}(\%)$.

\begin{tabular}{cccccc}
\hline & Rougher Ag Conc. & Rougher Pb Conc. & Scavenger Pb Conc. & Tailing & Total \\
\hline $\mathrm{PbSO}_{4}$ & 14.65 & 40.81 & 13.49 & 31.05 & 100 \\
$\mathrm{PbS}$ & 90.39 & 1.87 & 1.00 & 6.74 & 100 \\
$\mathrm{PbCO}_{3}$ & 2.36 & 61.87 & 16.86 & 18.91 & 100 \\
$\mathrm{~Pb}_{5}\left(\mathrm{P} / \mathrm{As} / \mathrm{VO}_{4}\right)_{3} \mathrm{Cl}$ & 9.92 & 14.51 & 14.25 & 61.32 & 100 \\
$\left(\mathrm{PbFe}_{6}(\mathrm{OH})_{12} \mathrm{SO}_{4}\right)_{4}$ & 5.69 & 85.03 & 4.13 & 5.15 & 100 \\
\hline
\end{tabular}

\subsubsection{Industrial Closed-Circuit Test}

An industrial closed-circuit test was carried out by the ore sample provider, Huachangshan Mountain Mining Company, Lanping Bai and Pumi Autonomous County, China. The main flowchart is shown in Figure 7, and the kind of reagent as well as their dosage are the same as in the laboratory flotation test. The grade and recovery rate of $\mathrm{Ag}$ concentrate and $\mathrm{Pb}$ concentrate are displayed in Table 6. The raw ore contains $3.11 \% \mathrm{~Pb}$ and $205 \mathrm{~g} / \mathrm{t} \mathrm{Ag}$. Obviously, there are some slight differences between industrial and laboratory samples. This is a normal phenomenon in industrial production.

Table 6. Results of the industrial closed-circuit test.

\begin{tabular}{cccccc}
\hline & & \multicolumn{2}{c}{ Ag } & \multicolumn{2}{c}{ Pb } \\
\cline { 3 - 6 } & Yield (\%) & Content (g/t) & Recovery (\%) & Content (\%) & Recovery (\%) \\
\hline Ag conc. & 5.97 & 1988 & 57.89 & 4.8 & 9.25 \\
Pb conc. & 7.76 & 786 & 29.75 & 23.4 & 58.46 \\
Tailing & 86.27 & 29 & 12.36 & 1.2 & 32.29 \\
\hline
\end{tabular}




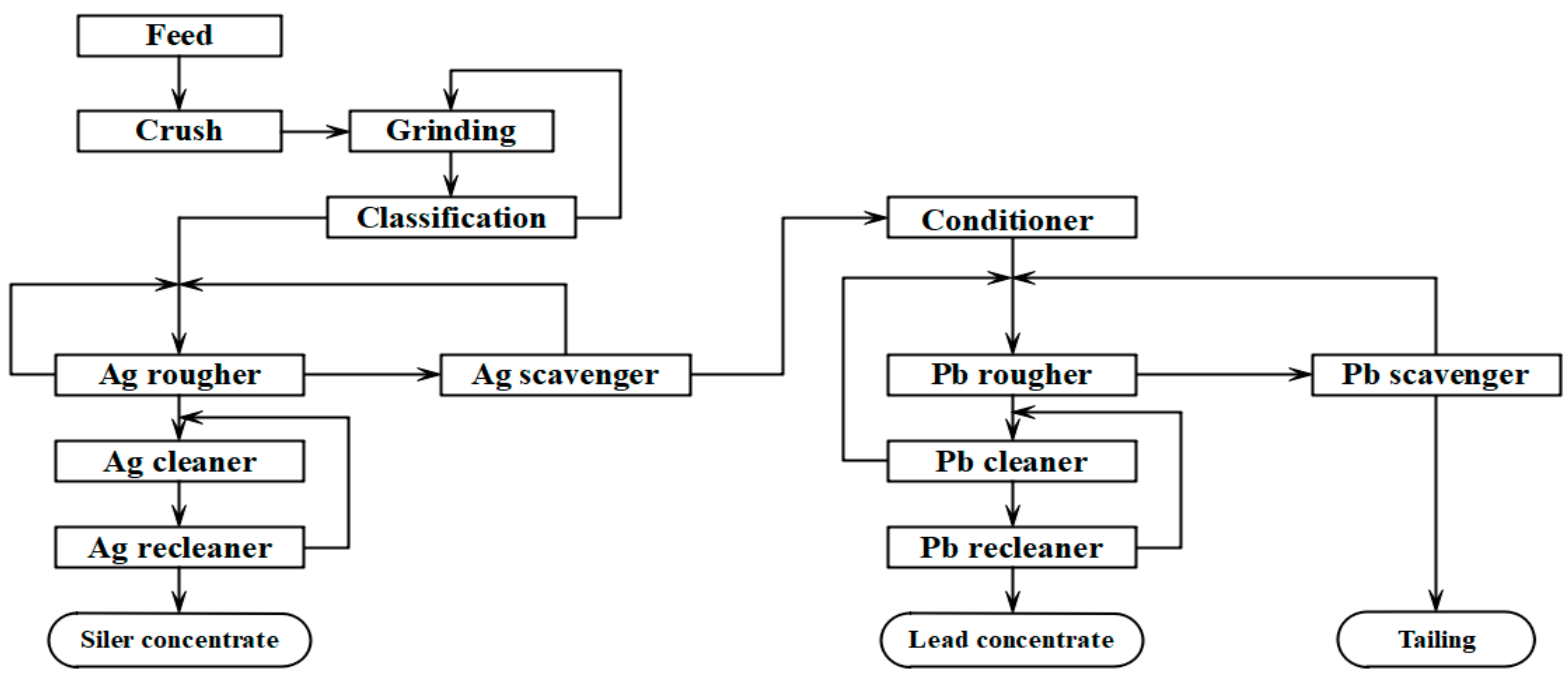

Figure 7. Industrial closed-circuit flotation flowchart.

In Table 6, the Ag concentrate contains $1988 \mathrm{~g} / \mathrm{t}$ Ag with 57.89\% recovery, and the $\mathrm{Pb}$ concentrate contains $23.4 \% \mathrm{~Pb}$ with $58.46 \%$ recovery.

\section{Conclusions}

In this study, we investigated a low-grade, mixed sulfide-oxide ore, containing lead and silver minerals, with complex mineralogy. The flotation findings demonstrated the sulfidizing flotation behaviors of these four different types of $\mathrm{Pb}$ minerals and three different types of Ag minerals, which provides valuable references for the separation of such minerals in the future. The selectivity of the commonly used silver flotation reagents was compared and a high-efficiency silver collector was found. An effective flotation process was successfully explored for this typical ore and an industrial closed-circuit test verified its feasibility and efficiency.

The main conclusions were as follows:

1. For the sulfidizing flotation behaviors of lead minerals, $\left(\mathrm{PbFe}_{6}(\mathrm{OH})_{12} \mathrm{SO}_{4}\right)_{4}$ and $\mathrm{PbCO}_{3}$ were quite easy to be sulfurized, $\mathrm{PbSO}_{4}$ could not be completely sulfurized, and only a small part of $\mathrm{Pb}_{5}\left(\mathrm{P} / \mathrm{As} / \mathrm{VO}_{4}\right)_{3} \mathrm{Cl}$ could be sulfurized. Therefore, the order of difficulty for sulfidizing all types of lead minerals was $\left(\mathrm{PbFe}_{6}(\mathrm{OH})_{12} \mathrm{SO}_{4}\right)_{4}<\mathrm{PbCO}_{3}$ $<\mathrm{PbSO}_{4}<\mathrm{Pb}_{5}\left(\mathrm{P} / \mathrm{As} / \mathrm{VO}_{4}\right)_{3} \mathrm{Cl}$. For silver minerals, $\mathrm{Ag}_{2} \mathrm{AsS}_{2}$ could be easily recovered at a lower dosage of $\mathrm{Na}_{2} \mathrm{~S}$, but with an increase in $\mathrm{Na}_{2} \mathrm{~S}$ dosage, the recovery rate of $\mathrm{Ag}_{2} \mathrm{AsS}_{2}$ gradually decreased. In contrast, natural-Ag and $\mathrm{AgCl}$ were basically depressed by sodium sulfide. Nevertheless, they were easily collected by xanthate and 3418A. Thus, the order of difficulty for sulfidizing all types of silver minerals was $\mathrm{Ag}_{2} \mathrm{AsS}_{2}<\mathrm{AgCl}<$ natural-Ag.

2. Ag minerals existed in the elemental form, and also in sulfide minerals and oxidized minerals. This made it impossible to effectively recover the silver which was partially present in the sulfide minerals by using only the sulfurization-xanthate method. Therefore, it was necessary to implement two flotation stages, the first stage for the sulfide minerals, and the second stage for the oxidized minerals, with the sulfurizationxanthate method. Most of the lead which existed in the oxidized minerals, could be effectively recovered by the sulfurization-xanthate method.

3. In the sulfide ore flotation stage, 3418A had the best selectivity for Ag and the least selectivity for $\mathrm{Pb}$, which was conducive to a higher grade of silver and a lower grade of lead. The yield of the product obtained by 3418A was low, which was favorable for industrial production.

4. The results of the laboratory tests showed that the silver found in natural-Ag, $\mathrm{AgCl}$, and $\mathrm{PbS}$ were recovered mainly in rougher $\mathrm{Ag}$, and the recovery rates were $84.36 \%$, 
and $82.14 \%$, and $88.78 \%$, respectively. $\mathrm{Ag}_{2} \mathrm{AsS}_{2}$ was mainly recovered in the rougher $\mathrm{Pb}$, and the recovery rate was 56.31\%. At the same time, $\mathrm{PbSO}_{4}, \mathrm{PbCO}_{3}$, and $\left(\mathrm{PbFe}_{6}(\mathrm{OH})_{12} \mathrm{SO}_{4}\right)_{4}$ were recovered in the rougher $\mathrm{Pb}$, with recovery rates of $40.81 \%$, $61.87 \%$, and $85.03 \%$, respectively. For lead minerals, the recovery efficiency of $\mathrm{Pb}_{5}\left(\mathrm{P} / \mathrm{As} / \mathrm{VO}_{4}\right)_{3} \mathrm{Cl}$ was quite low, and its recovery in rougher $\mathrm{Pb}$ and rougher $\mathrm{Ag}$ were $14.51 \%$ and $9.92 \%$, respectively, while the total recovery rate was only $38.68 \%$. The final results of the laboratory tests showed that the recovery rate of total Ag was $87.81 \%$ and the recovery rate of total $\mathrm{Pb}$ was $65.16 \%$. The results of the industrial closed-circuit test showed that the recovery rate of total Ag was $87.64 \%$ and the recovery rate of total $\mathrm{Pb}$ was $67.71 \%$ in lead concentrate.

Author Contributions: Writing—original draft, Y.Z.; Writing—review and editing, J.C. All authors have read and agreed to the published version of the manuscript.

Funding: This research was funded by National Natural Science Foundation of China (NSFC 51864003, NSFC 51874106), State Key program of the Joint Funds of the National Natural Science Foundation of China (Grant No.U20A20269) and Guangxi Natural Science Foundation (2018GXNSFAA050127). The authors are thankful for these supports.

Data Availability Statement: Not applicable.

Conflicts of Interest: The authors declare no conflict of interest.

\section{Appendix A}

Table A1. Pulp $\mathrm{pH}$ at different dosages of $\mathrm{Na}_{2} \mathrm{~S}$.

\begin{tabular}{cccccccccccc}
\hline $\mathbf{N a}_{\mathbf{2}} \mathbf{S}$ Dosage $(\mathbf{g} / \mathrm{t})$ & $\mathbf{0}$ & $\mathbf{1}$ & $\mathbf{2}$ & $\mathbf{3}$ & $\mathbf{4}$ & $\mathbf{5}$ & $\mathbf{6}$ & $\mathbf{7}$ & $\mathbf{8}$ & $\mathbf{9}$ & $\mathbf{1 0}$ \\
\hline $\mathrm{pH}$ & 6.0 & 6.5 & 7.0 & 7.5 & 8.0 & 8.5 & 9.0 & 9.5 & 10.0 & 11.0 & 12.0 \\
\hline
\end{tabular}

Table A2. The grade of $\mathrm{Ag}(\mathrm{g} / \mathrm{t})$.

\begin{tabular}{ccccc}
\hline & Rougher Ag Conc. & Rougher Pb Conc. & Scavenger Pb Conc. & Tailing \\
\hline $\mathrm{Natural} \mathrm{Ag}$ & 234.3 & 12.54 & 5.62 & 2.2 \\
$\mathrm{Ag}_{2} \mathrm{AsS}$ & 94 & 273.4 & 100.8 & 2.99 \\
$\mathrm{AgCl}$ & 685.06 & 65.56 & 29.14 & 3.8 \\
$\mathrm{PbS}$ & 176 & 3.36 & 1.85 & 1.65 \\
$\mathrm{SiO}_{2}$ \& Silicate & 91.5 & 116 & 69.8 & 6.4 \\
\hline
\end{tabular}

Table A3. The grade of $\mathrm{Pb}(\%)$.

\begin{tabular}{|c|c|c|c|c|}
\hline & Rougher Ag Conc. & Rougher Pb Conc. & Scavenger $\mathrm{Pb}$ Conc. & Tailing \\
\hline $\mathrm{PbSO}_{4}$ & 0.17 & 0.42 & 0.16 & 0.03 \\
\hline $\mathrm{PbS}$ & 1.91 & 0.03 & 0.02 & 0.01 \\
\hline $\mathrm{PbCO}_{3}$ & 0.32 & 7.14 & 2.19 & 0.16 \\
\hline $\mathrm{Pb}_{5}\left(\mathrm{P} / \mathrm{As} / \mathrm{VO}_{4}\right)_{3} \mathrm{Cl}$ & 1.64 & 2.07 & 2.28 & 0.86 \\
\hline$\left(\mathrm{PbFe}_{6}(\mathrm{OH})_{12} \mathrm{SO}_{4}\right)_{4}$ & 0.31 & 3.98 & 0.22 & 0.02 \\
\hline
\end{tabular}

\section{References}

1. Moradi, S.; Monhemius, A.J. Mixed sulfide-oxide lead and zinc ores: Problems and solutions. Miner. Eng. 2011, 24, 1062-1076. [CrossRef]

2. Liu, G.L.; Yang, X.L.; Zhong, H. Molecular design of flotation collectors: A recent progress. Adv. Colloid. Interfac. 2017, 246, 181-195. [CrossRef]

3. Jafari, M.; Shafaei, S.Z.; Abdollahi, H.; Gharabaghi, M.; Chehreh Chelgani, S. Effect of Flotation Reagents on the Activity of L. Ferrooxidans. Min. Proc. Ext. Met. Rev. 2018, 39, 34-43. [CrossRef]

4. Li, J.M.; Song, K.W.; Liu, D.W.; Zhang, X.L.; Lan, Z.Y.; Sun, Y.L.; Wen, S.M. Hydrolyzation and adsorption behaviors of SPH and SCT used as combined depressants in the selective flotation of galena from sphalerite. J. Mol. Liq. 2017, 231, 485-490. [CrossRef] 
5. Elizondo-Álvarez, M.A.; Dávila-Pulido, G.I.; Bello-Teodoro, S.; Uribe-Salas, A. Roleof pH on the adsorption of xanthate and dithiophosphinate onto galena. Can. Metall. Q. 2019, 58, 107-115. [CrossRef]

6. Jones, M.H.; Woodcock, J.T. Control of laboratory sulphidization with a sulphide ion-selective electrode before flotation of oxidized lead-zinc-silver dump material. Int. J. Miner. Process. 1979, 6, 17-30. [CrossRef]

7. Marabini, A.M.; Barbaro, M.; Passariello, B. Flotation of cerussite with a synthetic chelating collector. Int. J. Miner. Process. 1989, 25, 29-40. [CrossRef]

8. Rey, M.; Chataignon, P.; Formanek, V. Flotation of oxidised ores of lead, copper and zinc. Inst. Min. Metall. Trans. 1954, 63, 541-548.

9. Zhu, Y.; Sun, C.; Wu, W. A new synthetic chelating collector for the flotation of oxidized-lead mineral. J. Univ. Sci. Technol. Beijing Mineral. Metall. Mater. 2007, 14, 9-13. [CrossRef]

10. Fleming, M.G. Effects of alkalinity on the flotation of lead minerals. Trans. AIME 1952, 193, 1231-1236.

11. Chen, J.H.; Sun, C.Y. Study on the mechanism of sodium sulfide in the flotation system of cerusite. Met. Ore. Dress. Abroad 2006, 2, 19-20.

12. Chen, J.H.; Zhang, F.Q. Electrochemical properties of sulfidizing flotation system for cerusite. Min. Metall. Eng. 2017, 8, 38-40.

13. Wei, Z.W.; Chen, Y. On Flotation Performance of Cerusite in Xanthate System. Jiangxi Nonferrous Met. $2008,3,19-21$.

14. Martha, A.E.; Alejandro, U.S.; Fabiola, N.A. Flotation studies of galena (PbS), cerussite $\left(\mathrm{PbCO}_{3}\right)$ and anglesite $\left(\mathrm{PbSO}_{4}\right)$ with hydroxamic acids as collectors. Miner. Eng. 2020, 155, 106456.

15. Liu, S.Y.; Liu, D.W.; Li, J.L.; Cai, J.P.; Su, C. Progress on the surface sulfidization of cerussite flotation. Nonferrous Met. 2019, 2, 97-102.

16. Rashchi, F.; Dashti, A.; Arabpour-Yazdi, A.H. Anglesite flotation: A study for lead recovery from zinc leach residue. Miner. Eng. 2005, 18, 205-212. [CrossRef]

17. Rastas, J.; Nyberg, R. Hydro Metallurgical Process for the Recovery of Lead, Silver and Gold, as well as Zinc, from Impure Jarosite Residues of an Electrolytic Zinc Process. U.S. Patent 4,336,127, 28 December 1982.

18. Rastas, J.; Saari, M.; Hintikka, V.; Leppinen, J.; Jarvinen, A. Flotation Recovery of Lead, Silver, and Gold as Sulfides from Electrolytic Zinc Process. U.S. Patent 4,385,038, 24 May 1983.

19. Rastas, J.; Leppinene, J.; Hintikka., V.; Fugleberg, S. Recovery of lead, silver and gold from zinc process residue by a sulfidization flotation method. In The Minerals, Metals and Material Society; Mackey, T.S., Prengaman, R.D., Eds.; A Publication of The Minerals, Metals \& Materials Society (TMS): Pittsburgh, PA, USA, 1990; pp. 193-209.

20. Herrera-Urbina, R.; Sotillo, F.J.; Fuerstenau, D.W. Effect of sodium sulfide additions on the pulp potential and amyl xanthate flotation of cerussite and galena. Int. J. Miner. Process. 1999, 55, 157-170. [CrossRef]

21. Li, Y.; Wang, J.K.; Wei, C.; Liu, C.X.; Jiang, J.B.; Wang, F. Sulfidation roasting of low grade lead-zinc oxide ore with elemental sulfur. Miner. Eng. 2010, 23, 563-566. [CrossRef]

22. Fu, X.G. Evolution of Lanping Basin and formation of relevant metal deposits. J. Earth Sci. Environ. 2005, 27, 26-32.

23. Zhu, D.L. Geological characteristics of the Huachangshan Pb-Zn deposit and prospecting progress. Miner. Explor. 2013, 9 , 508-512.

24. Jiang, B. Mineralization of Sedimentary-Rock-Hosted Lead-Zinc Deposits of the Lanping-Simao Basin in Southern Part of Sanjiang Area. Ph.D. Thesis, China University of Geosciences (Beijing), Beijing, China, May 2014.

25. Han, P.; Wang, J.H.; Lu, A.X.; Ma, Z.D.; Pan, L.G. Analysis of heavy metal in soil with portable X-ray fluorescence spectrometry. Spectrosc. Spectr. Anal. 2012, 3, 826-829.

26. Huang, B.G. Advances in Chemical Phase Analysis in China. Anal. Chem. 1991, 19, 1215-1222.

27. Bulatovic, S.M. Handbook of Flotation Reagents Chemistry, Theory and Practice: Flotation of Sulfide Ores; Elsevier Science \& Technology Books Press: Amsterdam, The Netherlands, 2007; pp. 323-365.

28. Chen, Y.; Wen, S.M.; Wang, Y.J.; Feng, Q.C.; Li, J.L.; Cui, C.F. The Progress of Mineral Processing Technology of Lead-zinc Mine in China. Appl. Mech. Mater. 2014, 737, 874-877. [CrossRef] 